\title{
Different Responses of
}

\section{Proliferating and Resting Tumor HeLa Cells to Pulsed High Repetition Rate Low-Intensity Laser Light at $271 \mathrm{~nm}$}

\author{
T. I. KARU, ${ }^{*}$ G. S. KALENDO, $†$ V. S. LETOKHOV $\ddagger$ and V. V. LOBKO
}

"Laser Technology Center of the USSR Acad. Sci., 142092, Moscow Region, Troitzk; +National Cancer Research Center, 113408 Moscow, Kashirsky prospect, $6 \neq$ Institute of Spectroscopy of the USSR Acad. Sci., 142092, Moscow Region, Troitzk

(Received April 15, 1982)

The action of pulsed high repetition rate UV laser radiation (2-nd harmonic of $\mathrm{Cu}$ vapor laser, $\lambda=271 \mathrm{~nm}$, pulse duration $18 \mathrm{nsec}$, repetition rate $10 \mathrm{kHz}$ ) on proliferating and resting HeLa cells has been studied. The intensity of DNA synthesis changes after such kinds of irradiation for both types of cells. For proliferating cells DNA synthesis is suppressed, while for the resting ones stimulation is observed in the dose range from 0.05 to $5 \mathrm{~J} / \mathrm{m}^{2}$.

\section{INTRODUCTION}

The action of nonlaser UV radiation on biological objects has been well studied. ${ }^{1,2}$ With the advent of laser light sources, researches into the action of laser radiation with different wavelengths and intensities on biomolecules and organisms were started. ${ }^{3}$ A new source of UV radiation for such researches is based on the transformation of the radiation of a pulsed high repetition rate $\mathrm{Cu}$-vapor laser to the $\mathrm{UV}$ region. Such a laser radiates pulses at 510.5 and $578.2 \mathrm{~nm}$ at a frequency of $10 \mathrm{kHz}$, and with an average 
power of several watts. When these wavelengths are summed in a nonlinear crystal, it is possible to generate $\mathrm{UV}$ radiation at $271 \mathrm{~nm}$ with a frequency of $10 \mathrm{kHz}$, an average power up to $10^{-3} \mathrm{~W}$, and peak power up to $10 \mathrm{~W}$. Such a pulsed source of UV radiation is new for photobiology. In contrast to the continuous wave (CW) sources of $\mathrm{UV}$ radiation used in photobiology, its action is pulsed with high repetition rate. At the same time the pulse peak power is not enough for any nonlinear effects in biomolecules like those observed in Ref. 4. Therefore, the primary task of this work was to study the photobiological effect of pulsed UV laser radiation and compare it with CW UV radiation of a conventional source at the same irradiation dose.

The experiment has been performed on HeLa tumor cells grown to logarithmic phase (proliferating cells) or to stationary phase (resting cells). Such models have been chosen due to the fact that in cell populations (including real tumor tissues) alongside proliferating cells there is always some portion of cells not taking part in proliferation. ${ }^{5,6}$ These so-called resting cells can be nonproliferating for a long period of time, and therewith retain their viability. From this state the cells can return to the growth cycle under the action of an adequate stimulus. ${ }^{7}$ Resting cells are believed to be more resistant than proliferating ones to damaging factors. In this connection it is also of interest to compare the behavior of the resting and proliferating cells after the laser action is over. This is the second goal of the present study.

\section{MATERIALS AND METHODS}

\section{Cells}

Cultures of HeLa cells were grown as monolayers in glass flasks (with the bottom diameter of $24 \mathrm{~mm}$ ) in $2 \mathrm{ml}$ of feeding fluid consisting of 199 synthetic medium, supplemented with $15 \%$ bovine serum and antibiotics (100 units/ml canamycine or lincomycine). The cells were irradiated 72 hours after they were seeded (proliferating cells) when every flask contained $4.5 \pm 0.2 \times 10^{5}$ cells, or on the 8th, 10th, 11th and 13th day after the seeding (resting cells) when every flask contained $1.0 \pm 0.3 \times 10^{6}$ cells. After seeding the number of cells is constant (Figure 1) during some hours, then starts the active proliferation characterized by exponential increase of the cell number. The rate of growing is maintained until cells cease to divide and come to the stationary (or resting) state. After that begins the 


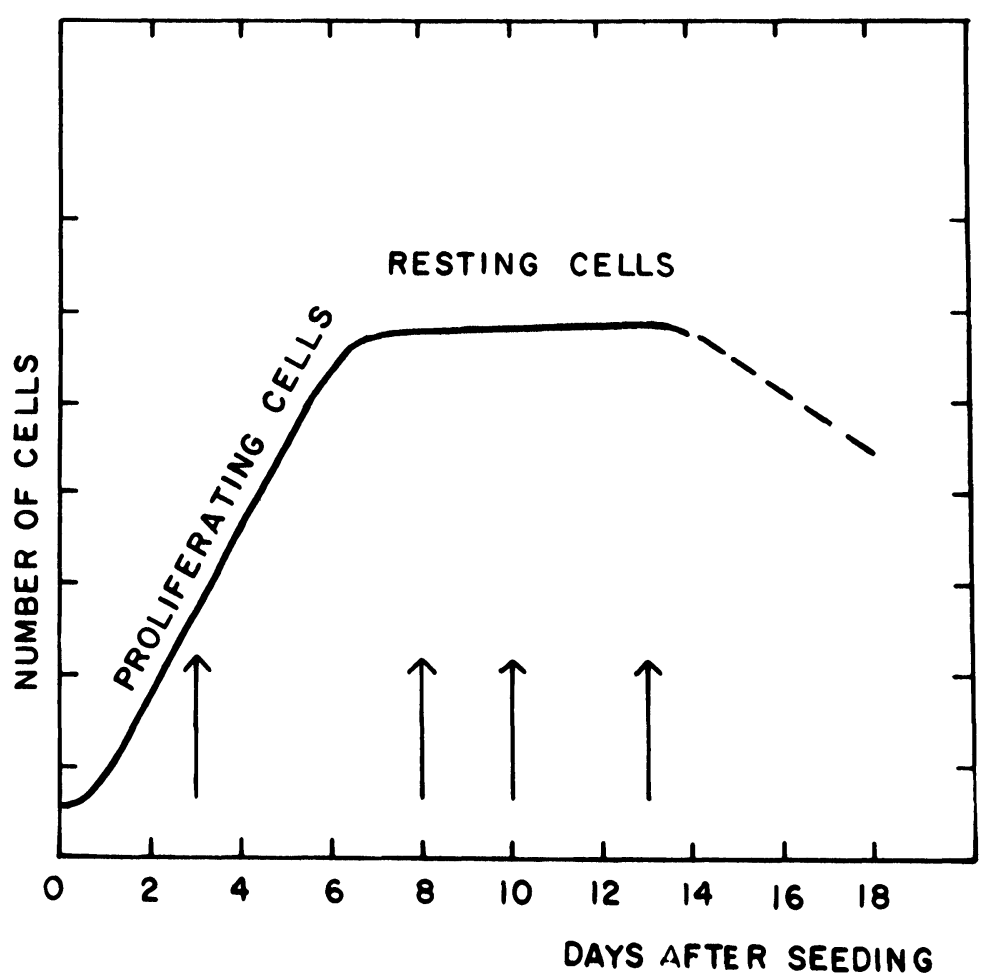

FIGURE 1 A scheme of the growth curve of HeLa cells in conditions of our experiment. The arrows show the days when the irradiation was performed.

degradation and death. So our experiments were performed with proliferating cells (3rd day after seeding) and with resting cells in four points of stationary growth: at the beginning (8th day), in the middle $(10,11$ th days) and at the end (13th day).

\section{Irradiation}

The cells were irradiated at $271 \mathrm{~nm}$ with laser pulses of $18 \cdot 10^{-9} \mathrm{sec}$ duration with repetition rate of $10 \mathrm{kHz}$. Also a standard commercial type mercury lamp with light filters, the radiation of which was focused by a quartz lens with focal length of $12 \mathrm{~cm}$, was used as an incoherent source of CW UV light $(\lambda=254 \mathrm{~nm})$. At the bottom surface of the cell flask 
the power density was $0.6 \mathrm{~W} / \mathrm{m}^{2}$. During irradiation the nutrient medium was removed from the flask, the flask was fixed to a special stand so that its bottom was perpendicular to the beam axis. Radiation was passed through the open plug of the flask and its beam diameter corresponded to the flask diameter.

The special experiment showed that the removal of the feeding medium for up to $5 \mathrm{~min}$ had no appreciable effect on the results. In all experiments the culture of cells without irradiation was used as control, and from the control flasks the feeding medium was evacuated for the same time as for irradiated ones. During the irradiation the temperature of the air around the flasks was kept approximately at $37^{\circ} \mathrm{C}$. After the irradiation the flasks were kept during 2.5 hours in a thermostat $\left(t=37^{\circ} \mathrm{C}\right)$ till labeling.

\section{Determination of the labeled precursors incorporation}

$2.5 \mathrm{~h}$ after the irradiation the culture was incubated at $37^{\circ} \mathrm{C}$ for $20 \mathrm{~min}$ in feeding medium containing $\mathrm{H}^{3}$-thymidine at $5 \mu \mathrm{Ci} / \mathrm{ml}$ (sp. act. $26.2 \mu \mathrm{Ci} /$ $\mathrm{mM}$ ) and $\mathrm{C}^{14}$-uridine at $1.5 \mu \mathrm{Ci} / \mathrm{ml}$ (sp. act. $52.8 \mathrm{mCi} / \mathrm{mM}$ ). Immediately after the incubation the monolayer was rinsed 3 times with ice-cold Hank's solution and kept with 5\% perchloric acid on icebath for $20 \mathrm{~min}$ to remove the acid-soluble pool. Then the cells were rinsed with ice-cold Hank's solution and kept for 10 min on icebath with absolute alcohol-ether (3:1 $\mathrm{v} / \mathrm{v}$ ) to extract the lipids. The cells were hydrolyzed with $5 \%$ perchloric acid $\left(t=80^{\circ} \mathrm{C}, 40 \mathrm{~min}\right)$, the liquid scintillator was added and the radioactivity of nucleic acids was measured by the SL-4221 type liquid scintillation counter ("Intertechnique," France). Each experimental point is the average value of the radiactivity measurements for 9 to 12 flasks.

\section{RESULTS}

The action of the second harmonic of a Cu-vapor laser on HeLa cells was studied with the radiation dose varying from $5 \times 10^{-2}$ to $2 \times 10^{2} \mathrm{~J} / \mathrm{m}^{2}$. DNA synthesis in both physiological states of the cells have found to be sensitive to this type of irradiation (Figure 2). The response of the proliferating and resting cells has proved to be opposite. In case of proliferating cells, DNA synthesis (Figure 2a) is decreased over the entire range of doses, i.e., the larger the dose the higher the suppression of DNA synthesis. At the 8th day after the seeding the culture is in the very beginning of the 
stationary state of growth. DNA synthesis' rate is decreased with dose increasing (Figure $2 b$ ). In other words, the response of these cells is like proliferating ones, only the rate of the decrease is less. Further the resting state of cells is deepening. In all cases of the resting cells beginning from the 10th day, over the same dose range, the DNA synthesis increases and reaches its maximum at the dose $0.5 \mathrm{~J} / \mathrm{m}^{2}$. At further increase in dose the rate of DNA synthesis decreases to the control level (Figure 2b). One can see that by deepening the resting state, the incorporation of $\mathrm{H}^{3}$-thymidine into unirradiated cells (control level) decreases. It seems to be connected with the decreasing of chromatins matrix activity and the increasing of its condensation during the deepening of the resting state. ${ }^{8}$

RNA synthesis has proved not to be very sensitive to the irradiation at

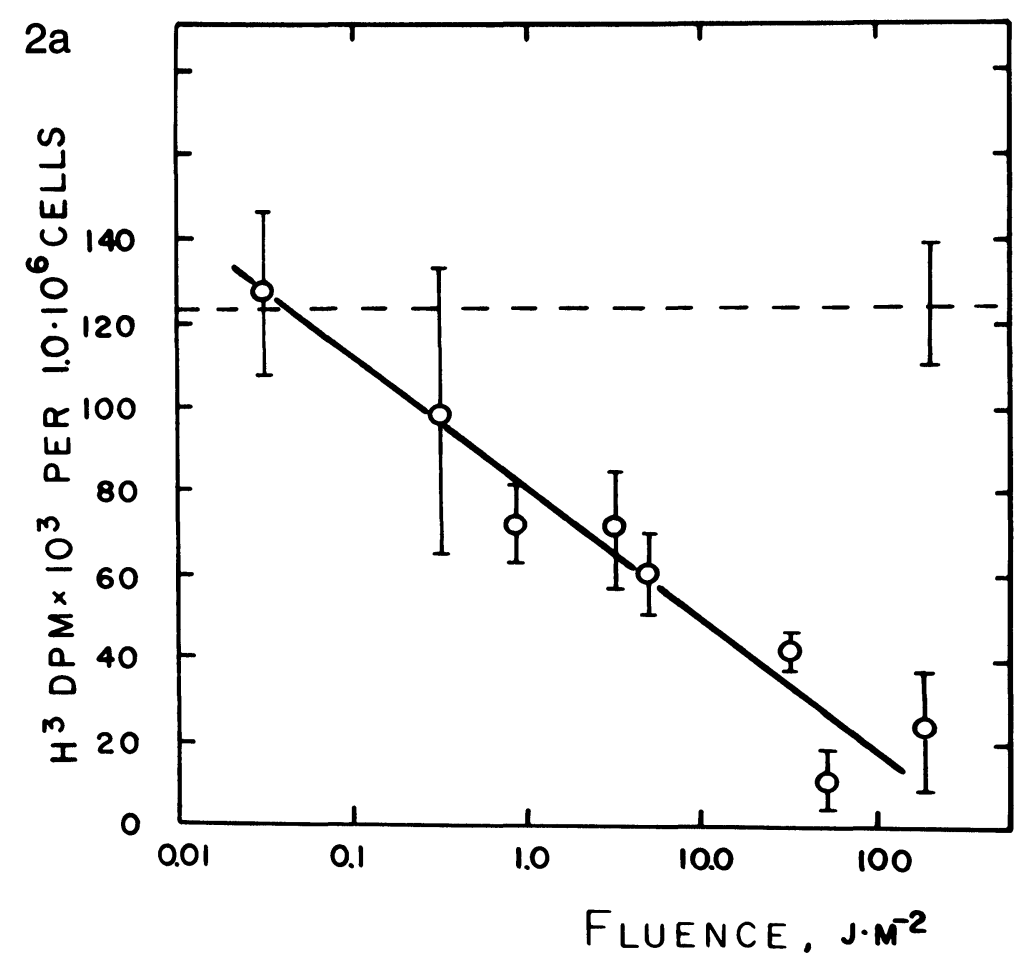

FIGURE 2 The effect of pulsed high repetition rate irradiation $(\lambda=271 \mathrm{~nm})$ on DNA synthesis for proliferating (a) and resting cells in different points of stationary state (b). The dashed lines denote the control level (nonirradiated cells). 


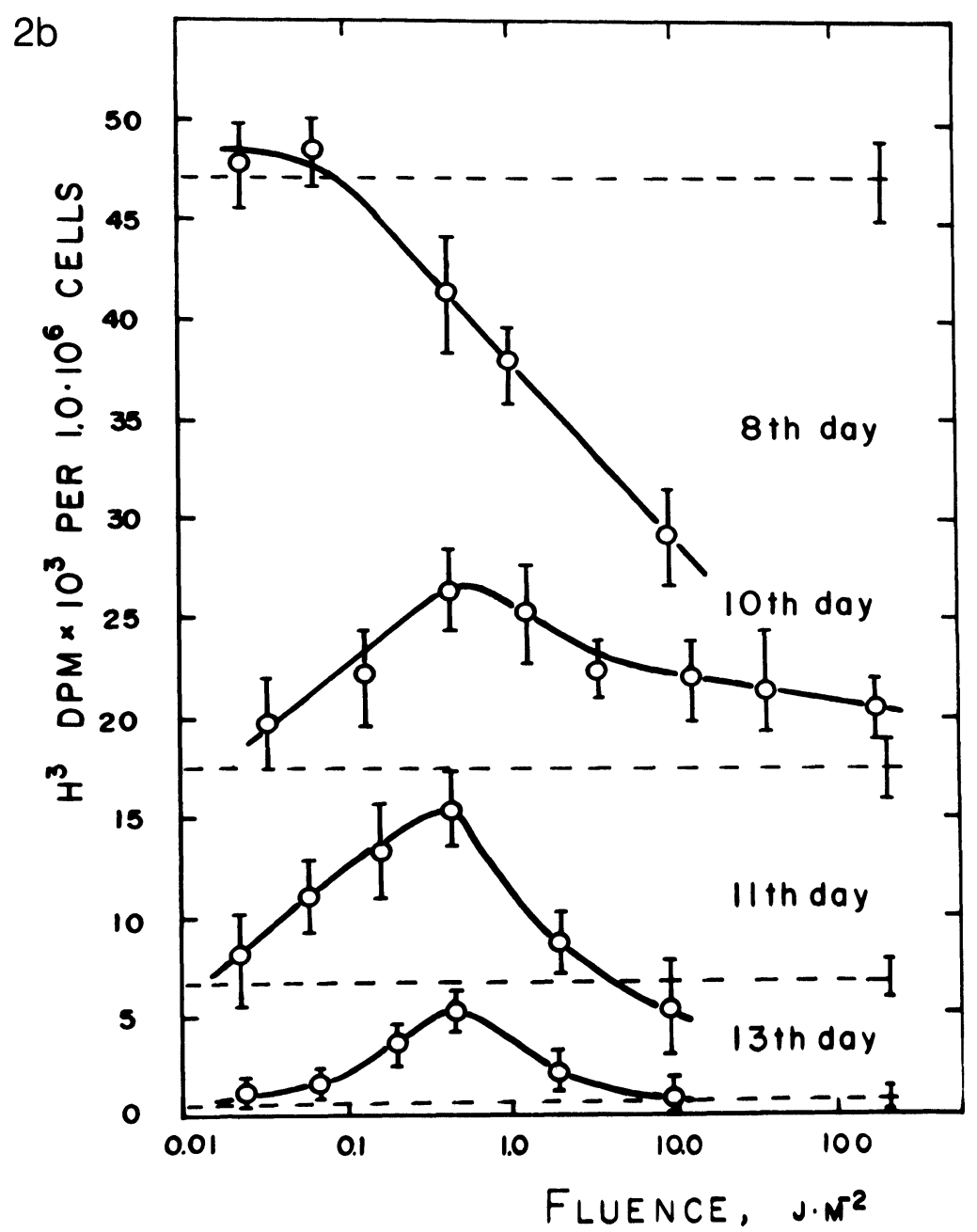

FIGURE 2 (continued)

$271 \mathrm{~nm}$ even though RNA as well as DNA can absorb at this wavelength. In the entire dose range (from $5 \cdot 10^{-2}$ to $2 \cdot 10^{2} \mathrm{~J} / \mathrm{m}^{2}$ ) the inclusion of $\mathrm{C}^{14}$-uridine remains at the control level in case of both proliferating and resting cells.

To compare the photobiological action of the UV pulses with high 
repetition rate with that of a CW UV source, we performed some experiments under exactly the same conditions with low-intensity CW UV radiation. Unfortunately, the wavelengths of $C W$ radiation $(\lambda=254 \mathrm{~nm})$ does not coincide with that of $\mathrm{Cu}$ laser second harmonic $(\lambda=271 \mathrm{~nm})$. Nevertheless, this wavelength falls within the absorption band of nucleic acids. As seen from Figure 3, the variation of DNA synthesis in the proliferating cells under the action of nonlaser continuous UV radiation is almost the same as in the case of pulsed irradiation: at small doses it remains at the control level and at increasing dose it becomes suppressed. In resting cells the rate of DNA synthesis remains practically on the control level over the entire range of doses (Figure 3 ).

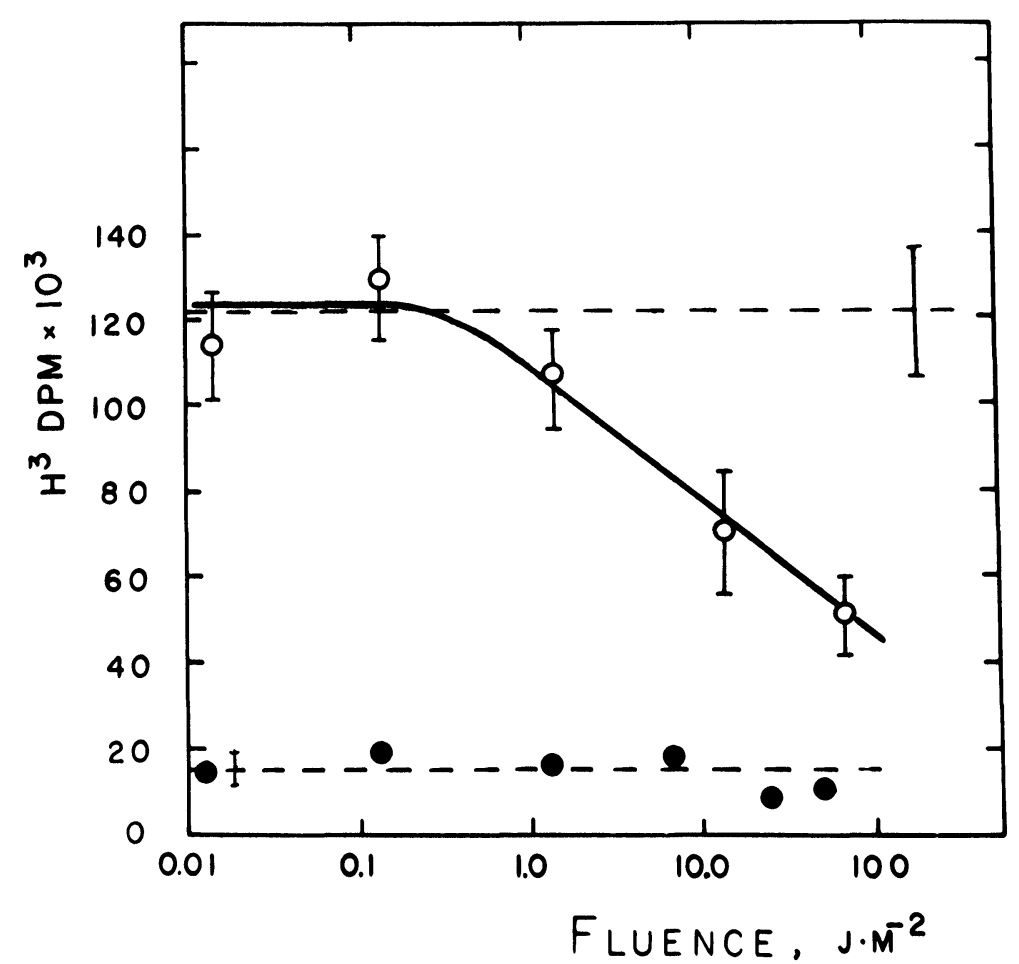

FIGURE 3 The effect of $\mathrm{CW}$ irradiation $(\lambda=254 \mathrm{~nm})$ on DNA synthesis: -0-0-০proliferating cells $\left(4.5 \cdot 10^{5}\right.$ cells $),-\bullet-\bullet-\bullet-$ resting cells $\left(1 \cdot 10^{6}\right.$ cells $)$. The dashed lines denote the control level (nonirradiated cells). 


\section{DISCUSSION}

This investigation is one of the first steps in seeking the possibilities for stimulation of resting tumor cells into proliferation by laser light. In this work it was found that the response of proliferating cells to irradiation with both UV sources pulsed with high repetition rate and CW is the same by character: at increasing doses the DNA synthesis decreases.

The situation is quite different in the case of resting cells. The UV irradiation causes the stimulation of the DNA synthesis in the case of a high repetition rate light, and no stimulation is observed for CW UV light. So we may conclude now that, apart from different responses of the proliferating and resting cells to pulsed irradiation, the resting cells respond to this kind of irradiation in a special way: DNA synthesis is stimulated in a dose range approximately from 0.05 to $5 \mathrm{~J} / \mathrm{m}^{2}$. The stimulation of DNA synthesis in proliferating cells by CW UV light is well known as "unscheduled" (not in the S phase) synthesis. ${ }^{9,10}$ But in our experiment we could not find any stimulation either in proliferating or in resting cells, by irradiating the cells with CW UV light. In both cases there was a suppression of DNA synthesis (Figure 3). In resting cells, CW UV radiation did not cause any effect. We guess that the pulsed character of radiation plays a significant role in causing DNA stimulation in resting cells. We have observed the similar phenomenon (the specific reaction of cells to pulsed high repetition rate radiation) in experiment on irradiation of HeLa cells by pulsed and CW laser irradiation at $\lambda=633 \mathrm{~nm} .{ }^{11}$ The molecular mechanisms of these phenomena are unclear at present and are the subject of our future work. It should be thought that one pulse causes some photochemical changes which do not relax before a new one arrives. Therefore we may assume that the functional state of the cells changes after one pulse, and the subsequent pulses act on the cell already in a changed functional state.

\section{Acknowledgment}

The authors are grateful to E. V. Yudakhina for technical assistance.

\section{References}

1. K. C. Smith (ed), The Science of Photobiology, Plenum Press, N.Y. 1977.

2. J. Jaegger, UV Photobiology, Prentice Hall Inc., Englewood Cliffs, 1967.

3. R. Pratesi and C. A. Sacchi, Lasers in Photomedicine and Photobiology, Springer Series in Optical Sciences, vol. 22, Springer-Verlag, Berlin-Heidelberg-New York, 1980. 
4. T. J. Karu, G. S. Kalendo, V. S. Letokhov, Yu. A. Matveetz, V. A. Semchishen and N. G. Serebrjakov, Sov. J. Quantum Electronics 8, pp. 2540-45, 1981 (in Russian).

5. F. Gavosto and A. Pileri, in Cell cycle and cancer, ed. by R. Baserga and M. Dekker. Inc. N.Y. pp. 99-128, 1971.

6. G. Andersson, J. Cell Physiol. 90, pp. 329-336, 1977.

7. O. I. Epifanova and V. V. Terskikh, Cell Tissue Kinet. 2, pp. 75-93, 1969.

8. M. Rossini, J. C. Lin and R. Baserga, J. Cell Physiol. 88, pp. 1-12, 1976.

9. R. E. Rasmussen and R. B. Pointer, J. Cell Biol. 29, pp. 11-19, 1966.

10. G. Moreno and C. F. Salet, Radiat. Res., 58, pp. 52-59, 1974.

11. T. J. Karu, G. S. Kalendo, V. S. Letokhov and V. V. Lobko, Sov. J. Quantum Electronics 9, No 9, pp. 1761-1767, 1982 (in Russian). 